\title{
Review
}

\section{Pretreatment Lignoselulosa dari Jerami Padi dengan Deep Eutectic Solvent untuk Meningkatkan Produksi Bioetanol Generasi Dua Lignocellulose Pretreatment of Rice Straw using Deep Eutectic Solvent to Increase Second-Generation Bioethanol Production}

\author{
Nurwahdah $^{\mathrm{a}}$, Al Arofatus Naini ${ }^{\mathrm{a}}$, Asma Nadia ${ }^{\mathrm{a}}$, Ratri Yuli Lestari ${ }^{\mathrm{b}, \mathrm{c}}$, Sunardi ${ }^{\mathrm{a}, \mathrm{ck}}$ \\ ${ }^{a}$ Chemistry Department, Faculty of Mathematics and Natural Sciences, \\ Lambung Mangkurat University, Banjarbaru 70714, Indonesia

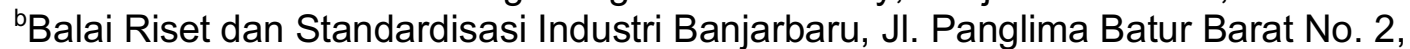 \\ Banjarbaru, Kalimantan Selatan \\ ${ }^{c}$ Wetland Resources for Environmental Sustainability Research Group, \\ Faculty of Mathematics and Natural Sciences, Lambung Mangkurat University, \\ Banjarbaru 70714, Indonesia \\ *Email: sunardi@ulm.ac.id
}

Diterima 30 Juli 2018 Disetujui 04 Desember 2018 Diterbitkan 28 Desember 2018

\begin{abstract}
ABSTRAK
Permasalahan sektor energi di Indonesia saat ini dapat dirangkum secara ringkas karena cadangan energi fosil yang semakin berkurang yang didominasi dengan bahan bakar fosil dan batu bara. Produksi minyak yang terus menurun dan kebutuhan bahan bakar minyak (BBM) yang terus meningkat menyebabkan impor minyak mentah serta BBM terus meningkat. Penggunaan limbah biomassa lignoselulosa sebagai material dasar menjadi alternatif utama untuk pengganti bahan bakar fosil dan produksi sediaan bahan kimia. Produksi padi total di Kalimantan Selatan pada tahun 2015 mencapai 2.140.276 ton dan jerami padi merupakan limbah yang sangat melimpah dan dapat digunakan sebagai bahan baku produksi bioetanol. Proses pretreatment lignoselulosa memegang peranan yang sangat penting dalam penghilangan lignin untuk produksi bioetanol karena ikatan silang kimia yang kompleks antar komponen-komponennya. Delignifikasi lignin mampu meningkatkan aksesibilitas dan digestibilitas enzimatik, kemudian membantu promosi hidrolisis enzimatik. Saat ini proses pretreatment dengan metode yang berbasis green chemistry terus dikembangkan oleh para peneliti untuk mengurangi biaya produksi serta menghindari efek yang merugikan terhadap manusia dan lingkungan. Artikel ini membahas tentang pretreatment dengan metode ramah lingkungan untuk material lignoselulosa non-kayu dengan menggunakan pelarut deep eutectic solvent (DES) untuk meningkatkan produksi bioetanol generasi dua di Kalimantan Selatan.
\end{abstract}

Kata Kunci: pretreatment, lignoselulosa, deep eutectic solvent, bioetanol

\section{ABSTRACT}

Current issues of energy sector in Indonesia can be summarized as depletion of fossil energy reserves which is dominated by fuel oil and coal. Oil production continues to decline and the increase in oil fuels demand lead to increase imports of crude oil and oil fuels. To use lignocellulosic biomass waste has become a major alternative to replace fossil fuels and chemical feedstocks production. In 2015, total rice production in South Kalimantan reached 2,140,276 ton and rice straws were abundant waste which could be utilized as raw material for bioethanol production. Pretreatment process of lignocellulose is a crucial step to remove lignin because of the complex chemical cross-linking between chemical components. Delignification of lignin can increase the accessibility and 
digestibility of enzymatic, and help to promote enzymatic hydrolysis. Nowadays, pretreatment process with green chemistry method is continuesly developed by researcher to reduce the production costs and thus avoid adverse effects on human and the environment. This article disscussed about green methods for pretreatment of lignocellulosic material using deep eutectic solvent (DES) to increase second-generation bioethanol production in South Kalimantan.

Keywords: pretreatment, lignocellulose, deep eutectic solvent, bioethanol

\section{PENDAHULUAN}

Produksi minyak yang terus menurun dan kebutuhan bahan bakar minyak (BBM) yang terus meningkat menyebabkan impor minyak mentah serta BBM terus meningkat (Boedoyo, 2008). Impor energi terbesar Indonesia pada tahun 2016 adalah minyak mentah dan kondensat (840.451 terajoule), BBM berkadar ringan (725.399 terajoule) dan BBM berkadar berat (269.526 terajoule) (BPS, 2017). Hal tersebut mendorong adanya pengembangan energi baru terbarukan sebagai alternatif pengganti bahan bakar fosil. Penggunaan lignoselulosa sebagai material dasar yang tidak bersaing dengan bahan pangan menjadi alternatif utama dalam pembuatan bioetanol (Ashraf \& Schmidt, 2017; Sert, Aslanoglu, \& Ballice, 2017). Biomassa lignoselulosa mengandung komponen utama selulosa, hemiselulosa, dan lignin. Salah satu biomassa lignoselulosa yang melimpah di Kalimantan Selatan dan dapat dimanfaatkan sebagai bahan baku pembuatan bioetanol generasi dua adalah jerami padi (Nata, Prayogo, \& Arianto, 2015).

Badan Pusat Statistik Kalimantan Selatan melaporkan bahwa produksi padi total pada tahun 2015 mencapai 2.140.276 ton yang tersebar di Kabupaten Tanah Laut, Kotabaru, Banjar, Barito Kuala, Tapin, Hulu Sungai Tengah (HST), Hulu Sungai Utara (HSU), Hulu Sungai Selatan (HSS), Tabalong, Tanah Bumbu, Balangan, dan Banjarmasin. Tanaman padi menghasilkan limbah berupa jerami, dedak, merang, dan sekam. Jerami yang dihasilkan dari total produksi padi adalah sebanyak 55,6\% (Nappu, 2013). Jerami padi mengandung $35,49 \%$ selulosa, $16,03 \%$ xylan, dan $14,84 \%$ lignin (Pan et al., 2017) yang dapat dimanfaatkan sebagai bahan baku dan dikonversi lebih lanjut menjadi bioetanol generasi dua. Proses konversi bahan lignoselulosa menjadi etanol terdiri atas beberapa tahap, yaitu pretreatment, hidrolisis, fermentasi, dan destilasi (Limayem \& Ricke, 2012). Proses pretreatment lignoselulosa memegang peranan yang sangat penting dalam penghilangan lignin untuk produksi bioetanol karena ikatan silang kimia yang kompleks antar komponen-komponennya. Delignifikasi lignin mampu meningkatkan aksesibilitas dan digestibilitas enzimatik, kemudian membantu promosi hidrolisis enzimatik (Pan et al., 2017).

Saat ini proses pretreatment dengan metode yang berbasis green chemistry terus dikembangkan oleh para peneliti untuk mengurangi biaya produksi serta menghindari efek yang merugikan terhadap manusia dan lingkungan. Pretreatment lignoselulosa menggunakan pelarut Deep Eutectic Solvents (DES) telah dilakukan pada beberapa biomassa seperti jerami padi (Pan et al., 2017), batang jagung (Xu et al., 2016), tongkol jagung (Zhang et al., 2016), dan Lactuca sativa (Procentese et al., 2017). DES telah mendapatkan perhatian sebagai pelarut alternatif yang sesuai karena bersifat tidak toksik, biokompatibilitas, kemudahan sintesis, dan ketersediaan komponen yang relatif murah sehingga memungkinkan untuk aplikasi secara besar (Kim, Dutta, Sun, Simmons, \& Singh, 2018). Oleh karena itu, review ini bermaksud membahas tentang pemanfaatan pelarut deep eutectic solvent (DES) sebagai metode pretreatment ramah lingkungan untuk material lignoselulosa non-kayu jerami padi untuk meningkatkan produksi bioetanol generasi dua. 


\section{KELIMPAHAN DAN PROSPEK LIGNOSELULOSA NON-KAYU DI KALIMANTAN SELATAN}

Biomassa lignoselulosa mengandung komponen utama selulosa, hemiselulosa, dan lignin (Moodley \& Kana, 2017). Selulosa merupakan polimer lurus unit Dglukosa yang terikat oleh ikatan $\beta-1,4-$ glikosidik, di mana gugus hidroksil dalam masing-masing unit membentuk ikatan hidrogen intra dan antarmolekul yang menguatkan rantai, membentuk struktur kaku, dan kristalin. Kristalinitas ini membentuk struktur selulosa yang lebih teratur dan membatasi akses enzim selama sakarifikasi (Chauve et al., 2013; Hall, Bansal, Lee, Realff, \& Bommarius, 2010;). Hemiselulosa merupakan struktur karbohidrat kompleks yang terdiri atas gula karbon lima dan enam seperti xilosa, arabinosa, glukosa, galaktosa, dan manosa. Pada dasarnya hemiselulosa menyediakan seluruh dinding sel dengan kekakuan lebih karena berinteraksi dengan serat mikro selulosa dan ikatan silang dengan lignin yang merupakan komponen primer ketiga dari dinding sel tanaman sekunder adalah polimer polifenol dan sangat tahan terhadap degradasi enzimatik (Pan et al., 2017; Pan, Kadla, Ehara, Gilkes, \& Saddler, 2006).

Bioetanol generasi pertama diproduksi melalui fermentasi gula dari gula tebu (Saccharum sp.) dan gula beet (Beta vulgaris L.) atau konversi pati dari gandum, jagung, barley, sorghum, dan umbi-umbian (Aiman, 2014; Walker, 2010). Sayangnya, penggunaan bahan baku tersebut untuk produksi bioetanol memunculkan konflik karena adanya persaingan antara bahan bakar dengan bahan pangan (Mohr \& Raman, 2013). Biomassa lignoselulosa mempunyai potensi yang besar untuk produksi bioenergi (seperti bahan bakar etanol) dan produksi bio-chemical karena kelimpahan, ketersediaan, dapat diperbaharui, dan tidak bersaing dengan bahan pangan (Chandel \& Singh, 2011; Phitsuwan, Sakka, \& Ratanakhanokchai, 2013). Dalam hal ini, sumber lignoselulosa yang paling menjanjikan di Kalimantan Selatan adalah limbah pertanian, limbah perkebunan, dan hasil hutan. Komposisi kimia berbagai biomassa lignoselulosa dapat dilihat pada Tabel 1.

Tabel 1. Komposisi Kimia Berbagai Lignoselulosa (\%)

\begin{tabular}{|c|c|c|c|c|}
\hline Biomassa Lignoselulosa & Selulosa (\%) & Hemiselulosa (\%) & \multicolumn{2}{|c|}{ Lignin (\%) Ekstraktif (\%) } \\
\hline L. Camara ${ }^{1}$ & $44,1 \pm 1,72$ & - & $32,25 \pm 1,57$ & - \\
\hline Jerami Padi² & $28-36$ & $23-28$ & $12-14$ & - \\
\hline Jerami Gandum $^{2}$ & $33-38$ & $26-32$ & $17-19$ & - \\
\hline Ampas Tebu ${ }^{2}$ & $32-48$ & $19-24$ & $23-32$ & - \\
\hline Batang Sorghum ${ }^{2}$ & 27 & 25 & 11 & - \\
\hline Batang Jagung $^{3}$ & 33,4 & 21,8 & 11,2 & 9,3 \\
\hline Tongkol Jagung 4 & $40-44$ & $31-33$ & $16-18$ & - \\
\hline Pelepah Nipah (Nypa fruticans) ${ }^{5}$ & 35,1 & 26,4 & 17,8 & 1,9 \\
\hline Purun Tikus ${ }^{6}$ & 32,62 & - & 26,4 & 9,53 \\
\hline Alang-alang (Imperata cilindri ca) & 51,6 & 77,69 & 22,07 & 18,26 \\
\hline Pelepah Kelapa Sawit ${ }^{8}$ & 40,01 & 30,78 & 29,50 & - \\
\hline Tandan Kosong Kelapa Sawit ${ }^{8}$ & 30,85 & 13,94 & 36,40 & - \\
\hline Kayu Keras ${ }^{9}$ & $40-55$ & $24-40$ & $18-25$ & - \\
\hline Kayu Lunak ${ }^{9}$ & $45-50$ & $25-35$ & $25-35$ & - \\
\hline Jerami Sorghum $^{10}$ & $32-35$ & $24-27$ & $15-21$ & - \\
\hline Rumput-rumputan ${ }^{10}$ & $25-40$ & $25-50$ & $10-30$ & - \\
\hline
\end{tabular}

Sumber : ${ }^{1}$ Kuhad et al., 2010; ${ }^{2}$ Reddy \& Yang, 2005; ${ }^{3)}$ Kamireddy et al., 2013; 4)Wang et al.,2011; ${ }^{5)}$ Tamunaidu \& Saka, 2011; ${ }^{6}$ Sunardi \& Istikowati, 2012; ${ }^{7)}$ Liong et al., 2013; \& ${ }^{8}$ Kristiani et al., 2013; ${ }^{9}$ Anwar, Gulfraz, \& Irshad, 2014; ${ }^{10}$ Isikgor \& Becer, 2015). 
III. PRETREATMENT LIGNOSELULOSA UNTUK PRODUKSI BIOETANOL GENERASI KEDUA

Pretreatment merupakan tahapan pertama dalam proses biokonversi lignoselulosa menjadi bioetanol (Balat, Balat, \& Oz, 2008). Tujuan utama dari proses pretreatment adalah untuk mengurangi berbagai senyawa yang dapat menghambat laju hidrolisis seperti lignin, mengurangi degradasi holoselulosa sehingga menghasilkan total karbohidrat yang tinggi, mereduksi sifat kristalinitas selulosa, dan meningkatkan permukaan kontak enzim (Daud, Safii, \& Syamsu, 2012; Zhang et al., 2016). Delignifikasi lignin mampu meningkatkan aksesibilitas dan digestibilitas enzimatik, kemudian membantu promosi hidrolisis enzimatik dari gula sederhana yang berasal dari selulosa dan hemiselulosa sehingga diperoleh rendemen gula tinggi yang selanjutnya difermentasi menjadi etanol (Daud et al., 2012; Pan et al., 2017). Skema delignifikasi bahan berlignoselulosa dapat dilihat pada Gambar 1. Pretreatment lignoselulosa dapat dikelompokkan menjadi empat metode yaitu pretreatment secara kimia, fisika, fisika-kimia, dan biologi. Rangkuman berbagai metode pretreatment lignoselulosa untuk produksi bioetanol generasi kedua dapat dilihat pada Gambar 2.

Pretreatment lignoselulosa secara kimia telah banyak diteliti di antaranya dengan pretreatment asam, basa, organosolv, oksidatif, sub/supercritical liquefaction, dan green solvents (Kuhad et al., 2010; Mazaheri et al., 2010; Pan et al., 2017; Pang, Lyu, Dong, Li, \& Yang, 2016; Yoon et al., 2011; Zhao et al., 2008). Pretreatment asam bisa menggunakan asam pekat maupun asam encer. Hidrolisis menggunakan asam pekat menghasilkan gula yang tinggi ( $90 \%$ dari hasil teoritik) dibandingkan dengan hidrolisis asam encer, sehingga kadar etanol yang dihasilkan akan lebih tinggi. Namun, perlakuan dengan asam pekat dapat meningkatkan pembentukan senyawa inhibitor, menyebabkan korosi pada peralatan, dan sulit me-recovery asam yang digunakan (Hou, Ding, Qiu, Zhang, \& Xianga, 2017). Pretreatment biomassa alang-alang dengan konsentrasi asam sulfat encer $2,0 \%$, temperatur $140^{\circ} \mathrm{C}$, waktu hidrolisa 150 menit dan menggunakan ragi tape hari ketiga memberikan kadar alkohol tertinggi sebesar 5,0675\% (Osvaldo, Putra, \& Faizal, 2012). Pretreatment menggunakan basa lebih efektif untuk melarutkan lignin, kurang dalam mendegradasi selulosa dan hemiselulosa, polusi rendah, dan tidak bersifat korosif (Moodley \& Kana, 2017). Pretreatment menggunakan $\mathrm{NaOH}$ mampu meningkatkan degradasi kayu keras dari $14 \%$ menjadi $55 \%$ dan kadar lignin berkurang dari $55 \%$ menjadi $20 \%$ (Kumar, Barrett, Delwiche, \& Stroeve, 2009a).

Pretreatment secara fisika terutama bertujuan untuk mengurangi ukuran partikel bahan baku. Pretreatment secara fisika lebih ramah lingkungan dibandingkan pretreatment menggunakan asam pekat karena tidak menghasilkan residu berbahaya. Berbagai pretreatment seperti ball mill reactor, pirolisis, autohidrolisis, sinar iradiasi, dan gelombang ultrasonik memerlukan banyak energi sehingga kurang layak secara ekonomi. Selain itu, pretreatment secara fisika kurang optimal untuk memecah lignin dan xilan (Chung et al., 2012; Mais, Esteghlalian, Saddler, \& Mansfield, 2002; Yunus et al., 2010).

Pretreatment fisika-kimia merupakan pretreatment yang menggabungkan proses secara fisika dan kimia. Beberapa contoh pretreatment fisika-kimia yaitu Ammonia Fiber Explosion (AFEX), liquid hot water, superfine grinding, steam explosion, steam salt-alkali, dan microwave salt-alkali (Girio et al., 2010; Moodley \& Kana, 2017). Penggunaan garam alkali atau garam anorganik sebagai pelarut steam atau microvawe pretreatment menunjukkan efisiensi yang tinggi terhadap hidrolisis enzimatik. Steam salt-alkali (SSA) dan microwave salt-alkali (MSA) mampu mendelignifikasi lignin masing-masing $80,5 \%$ dan $73 \%$. Selain itu, keuntungan pretreatment dengan SSA dan MSA adalah waktu pretreatment yang singkat dalam skala besar menurunkan konsumsi energi 
sehingga mengurangi biaya produksi. Garam alkali atau garam anorganik seperti $\mathrm{NaOH}, \mathrm{ZnCl}_{2}$, dan lainnya bersifat non korosif, polusi yang rendah bahkan non polusi, toksisitas yang sangat rendah, dan mempunyai kemampuan aktivitas katalis yang tinggi (Moodley \& Kana, 2017). Serat yang dilarutkan dalam $65 \%$ berat larutan $\mathrm{ZnCl}_{2}$ merusak sejumlah besar ikatan hidrogen intramolekul dan intermolekul yang menyebabkan penghancuran wilayah kristal, di mana molekul selulosa terpisah satu sama lain (Li \& Song, 2018). Berdasarkan hasil penelitian, SSA dan MSA merupakan metode pretreatment yang menjanjikan untuk dikembangkan dalam produksi bioetanol.

$$
\text { Pretreatment secara biologi }
$$

menggunakan pendegradasi kayu seperti jamur pembusuk putih dan cokelat, serta jamur pembusuk lunak mampu mengubah komposisi kimia dan struktur biomassa lignoselulosa (Kumar, Sing, \& Ghosh, 2009b; Walker, 2010). Pretreatment secara biologi memiliki beberapa kelebihan yaitu pemakaian energi yang rendah, tidak menggunakan bahan kimia, dampak terhadap lingkungan sedikit, dan tidak dihasilkan zat inhibitor. Namun, laju hidrolisis yang dihasilkan masih rendah, sebagian besar mikroorganisme lignolitik juga mengkonsumsi hemiselulosa dan selulosa, proses pretreatment-nya memerlukan waktu yang lama, dan pertumbuhan mikroorganisme perlu terus dikontrol (Menon \& Rao, 2012).

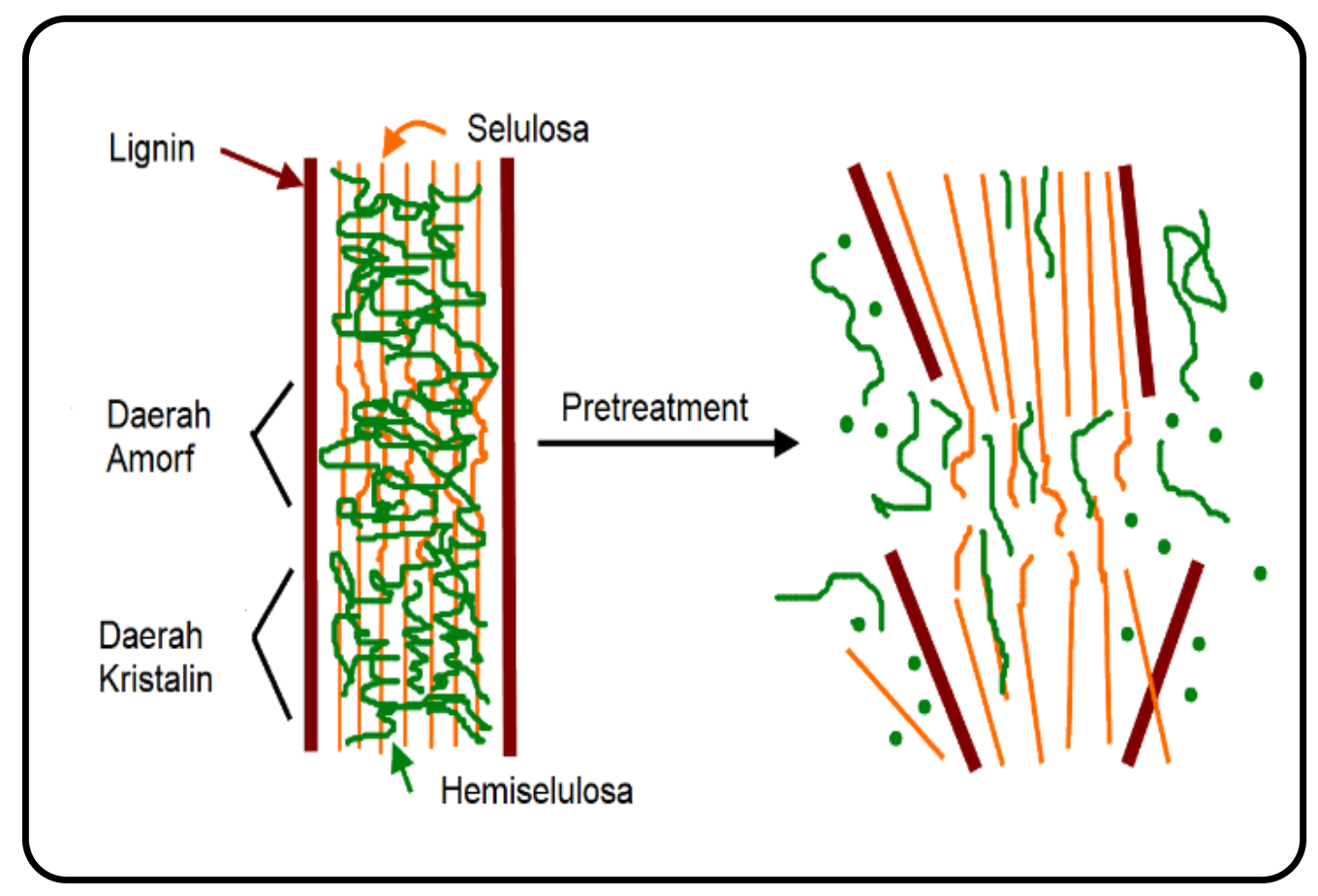

Gambar 1. Skema Pretreatment Bahan Lignoselulosa (Mosier et al., 2005) 


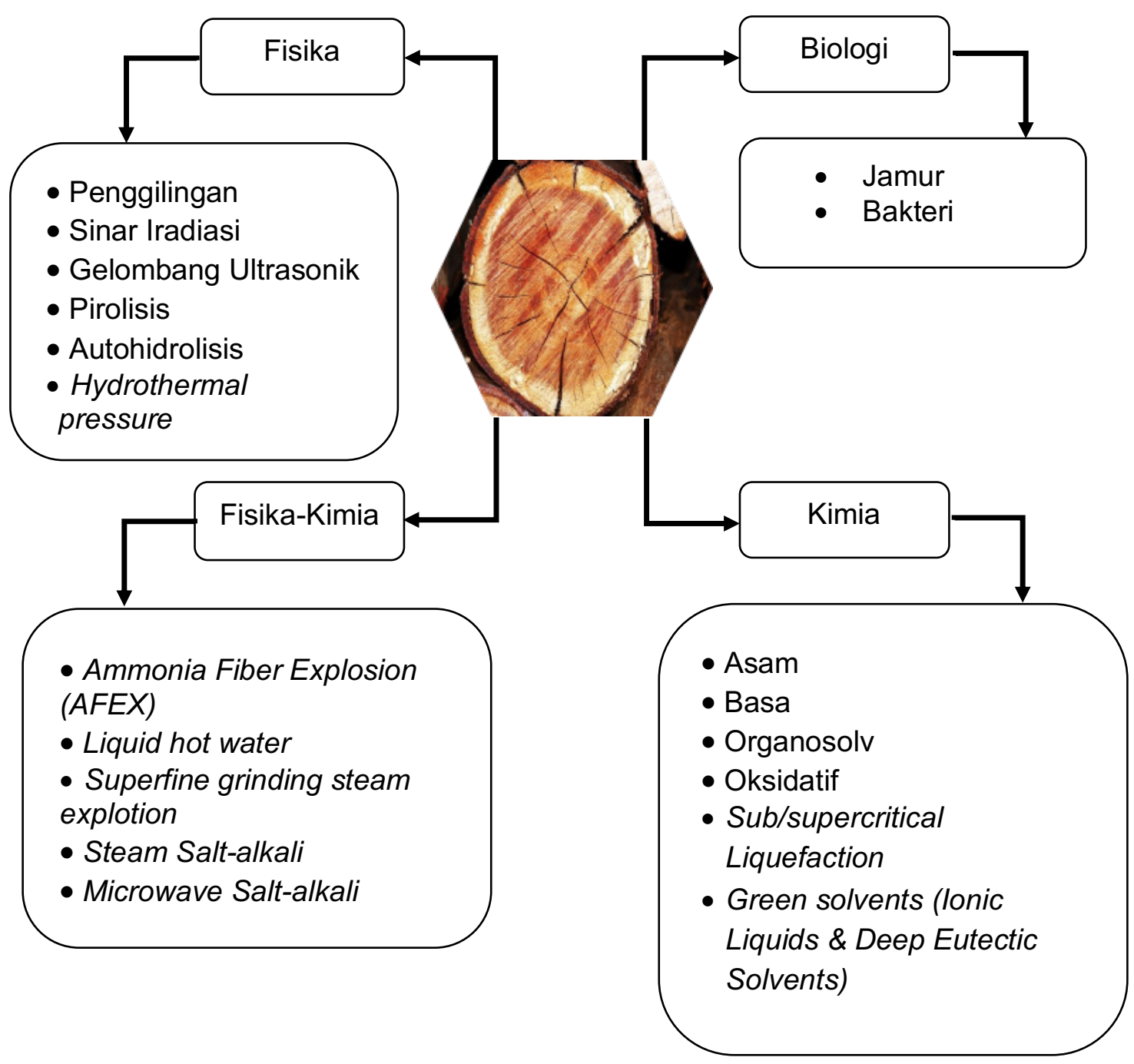

Gambar 2. Metode Pretreatment Lignoselulosa untuk Produksi Bioetanol Generasi Kedua

IV. DEEP EUTECTIC SOLVENTS (DES) SEBAGAI ALTERNATIF PRETREATMENT LIGNOSELULOSA RAMAH LINGKUNGAN

Baru-baru ini, metode lonic liquds (ILs) mendapatkan perhatian yang besar sebagai pelarut baru untuk pretreatment biomassa lignoselulosa karena sifat pelarut yang lebih ramah lingkungan dan lebih efisien (Kim, Ding, Qiu, Zhang, \& Xianga, 2017; Pang et al., 2016). Secara umum, ILs merujuk pada kelompok garam cair dengan titik leleh rendah $\left(<100^{\circ} \mathrm{C}\right)$. Menyerupai kemampuan pelarut universal, tekanan uap yang dapat diabaikan dan stabilitas termal yang tinggi, dapat dikombinasikan dengan berbagai kation dan anion, tidak mudah terbakar, dan bahan kimia yang stabil (Socha et al., 2014; Wahlstrom \& Suurnakki, 2015; Wu et al., 2014). Pretreatment menggunakan ILs dapat terjadi di bawah kondisi yang lebih ringan dan ILS dapat didaur ulang dan digunakan kembali setelah pemrosesan biomassa. ILs mampu menghilangkan lignin dan menjangkau struktur kristalinitas selulosa yang dapat meningkatkan aksesibilitas dan digestibilitas enzimatik. Namun, penggunaan ILs masih terbatas karena harganya yang mahal, sifat biodegradable yang rendah, dan kemungkinan bersifat toksik (Li \& Zhong, 2013; Procentese et al., 2015). 
Tabel 2. Komposisi Kimia dari Jerami Padi Dengan dan Tanpa Pretreatment Choline Chloride $(\mathrm{ChCl}) /$ Urea

\begin{tabular}{ccccc}
\hline Kondisi pretreatment & \multicolumn{4}{c}{ Komposisi $(\%)^{\text {a }}$} \\
\cline { 2 - 5 } sampel & Selulosa & Xylan & Lignin & Ekstraktif \\
\hline Tanpa pretreatment & $35,49(0,55)^{\mathrm{b}}$ & $16,03(0,42)$ & 14,84 & $6,36(0,06)$ \\
$110^{\circ} \mathrm{C}, 4$ jam & $26,76(0,81)$ & $12,34(0,23)$ & 8,72 & $6,08(2,17)$ \\
$110^{\circ} \mathrm{C}, 6$ jam & $27,77(0,28)$ & $12,27(0,07)$ & 10,08 & $5,87(0,57)$ \\
$110^{\circ} \mathrm{C}, 8$ jam & $28,19(0,31)$ & $12,51(0,16)$ & 9,90 & $3,86(1,29)$ \\
$130^{\circ} \mathrm{C}, 4$ jam & $24,22(0,53)$ & $10,96(0,80)$ & 9,54 & $4,21(0,96)$ \\
$130^{\circ} \mathrm{C}, 6$ jam & $25,06(2,70)$ & $11,55(1,34)$ & 8,43 & $3,36(0,60)$ \\
$130^{\circ} \mathrm{C}, 8$ jam & $26,20(1,10)$ & $12,43(1,37)$ & 8,20 & $4,57(0,97)$ \\
\hline
\end{tabular}

Sumber : Pan et al. (2017)

Deep Eutectic Solvents (DES) telah mendapatkan perhatian sebagai pelarut alternatif yang sesuai dibandingkan dengan ILs. DES biasanya dibentuk dengan mengombinasikan garam kuarterner seperti Choline chloride $(\mathrm{ChCl})$ yang berperan sebagai akseptor dan donor ikatan hidrogen seperti alkohol atau asam karboksilat. Interaksi donor ikatan hidrogen dengan garam kuarterner mengurangi kekuatan elektrostatik kation anion yang secara signifikan menyebabkan penurunan titik beku dalam campuran. DES mempunyai sifat pelarut yang menjanjikan dibandingkan ILs yaitu mempunyai volatilitas yang rendah, rentang cairan yang lebar, tidak toksik, biokompatibilitas, kemudahan sintesis, dan ketersediaan komponen yang relatif murah sehingga memungkinkan untuk aplikasi secara besar (Kim et al., 2018). Perbandingan komposisi kimia jerami padi dengan dan tanpa pretreatment ditunjukkan di Tabel 2 .

Jumlah asam, kekuatan asam, dan sifat akseptor ikatan hidrogen memberikan pengaruh besar terhadap hasil pretreatment. Beberapa contoh hasil pretreatment lignoselulosa dengan DES dapat dilihat pada Tabel 3. Polialkohol/Choline chloride mempunyai kemampuan tinggi untuk mengekstrak lignin dan meningkatkan yield glukosa. Pretreatment jerami padi dengan Choline chloride/Urea mampu mengubah formasi ikatan hidrogen intraseluler selulosa. Choline chloride : asam oksalat dengan kondisi temperatur $90^{\circ} \mathrm{C}$ selama 24 jam menunjukkan kemampuan yang tinggi untuk melarutkan lignin, yaitu lignin yang terekstrak mencapai 98,5\%. Lignin yang terekstrak meningkat drastis dari $77,9 \%$ menjadi $93,1 \%$ ketika rasio molar choline chloride: asam laktat diubah dari 1:5 menjadi 1:15. Akan tetapi, yield glukosa yang dihasilkan juga berubah dari 83,5\% menjadi $79,1 \%$. Yield glukosa tertinggi yang dihasilkan yaitu dengan DES choline chloride: gliserol sebanyak $96,4 \%$ dengan lignin terekstrak sebanyak $71,3 \%$. Hal ini mengindikasikan bahwa jumlah asam dalam DES dapat memfasilitasi untuk pengurangan lignin dan mengurangi recovery residu (Pan et al., 2017; Zhang et al., 2016).

\section{KESIMPULAN}

Kelimpahan lignoselulosa di Kalimatan Selatan yang bersumber dari limbah pertanian contohnya adalah jerami padi. Kandungan selulosa dan hemiselulosa yang cukup tinggi pada jerami padi dapat dimanfaatkan sebagai bahan baku pembuatan bioetanol generasi kedua. DES dapat digunakan sebagai media yang menjanjikan untuk delignifikasi karena sifatnya yang ramah lingkungan dan harganya yang relatif lebih murah. Kondisi optimum pelarut Choline chloride/Urea pada pretreatment limbah jerami padi yaitu pada suhu $130^{\circ} \mathrm{C}$ selama 4 jam. 


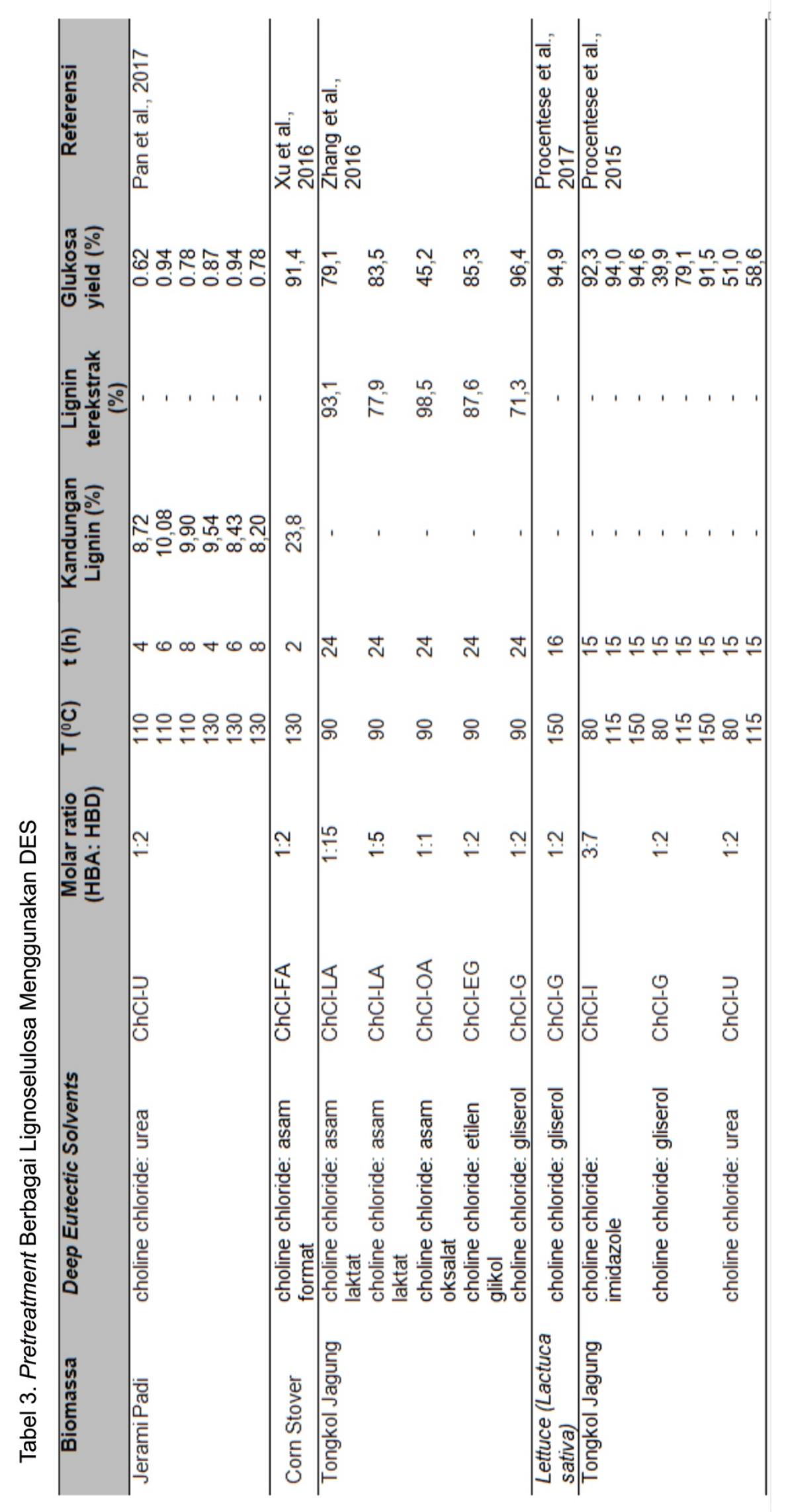




\section{DAFTAR PUSTAKA}

Aiman, S. (2014). Perkembangan Teknologi dan Tantangan dalam Riset Bioetanol di Indonesia. JKTI, 16 (2), 108-117.

Anwar, Z., M. Gulfraz, \& M. Irshad. (2014). Agro-industrial Lignocellulosic Biomass A Key To Unlock The Future Bio-Energy: A Brief Review. Journal of Radiation Research and Applied, 1-11.

Ashraf, M.T. \& Schmidt, J. E. (2017). Process Simulation and Economic Assessment of Hydrothermal Pretreatment and Enzymatic Hydrolysis of Multi-feedstock Lignocellulose-Separate vs Combining Processing. Bioresource Technology, 249, 835-843.

Balat, M., Balat, H. \& Oz, C. (2008). Progress in Bioethanol Processing. Progress in Energy and Combustion Science, 34, 551-573.

Boedoyo, M. S. (2008). Pengembangan Teknologi Energi Alternatif untuk Mendukung Ketahanan dan Kemandirian Energi Nasional. Jakarta: BPPT.

BPS. (2017). Neraca Energi Indonesia 2012-2016. Jakarta: Badan Pusat Statistik-Statistics Indonesia.

Chandel, A. K. \& Singh, O. V. (2011). Weedy Lignocellulosic Feedstock and Microbial Metabolic Engineering, Advancing The Generation of 'Biofuel'. Applied Microbial Biotechnology, 89, 12891303.

Chauve, M., Barre, L., Tapin-Lingua, S. Perez, Dd. S., Decottignies, D., Perez, S. \& Ferreira, N. L. (2013). Evolution and Impact of Cellulose Architecture During Enzymatic Hydrolysis by Fungal Cellulases. Advances in Bioscience and Biotechnology, 04, 1095-1109.

Chung, B. Y., Lee, J. T., Bai, H. W. Kim, U. J., Bae, H. J., Wi, S. G., \& Cho, J. Y. (2012). Enhanced Enzymatic
Hydrolysis of Poplar Bark by Combined Use of Gamma Ray and Dilute Acid for Bioethanol Production. Radiation Physics and Chemistry, 81, 1003-1007.

Daud, M., Safii, \& Syamsu, K. (2012). Biokonversi Bahan Berlignoselulosa menjadi Bioetanol Menggunakan Aspergillus Niger dan Saccharomyces cereviciae. Jurnal Perennial, 8 (2), 43-51.

Gírio, F. M., Fonseca, C., Carvalheiro, F., Duarte, L. C., Marques, S., \& BogelŁukasik, R. (2010). Hemicelluloses for Fuel Ethanol, A Review. Bioresource Technology, 101, 4775- 4800.

Hall. M., Bansal, P., Lee, J.H., Realff, M.J. \& Bommarius, A.S. (2010). Cellulose Crystallinity A Key Predictor of The Enzymatic Hydrolysis Rate. FEBS Journal, 277, 1571-1582.

Hou, J., Ding, C., Qiu, Z., Zhang, Q., \& Xianga, W. (2017). Inhibition Efficiency Evaluation of Lignocellulose-derived Compounds for Bioethanol Production. Journal of Cleaner Production, 165, 11071114.

Isikgor, F.H, \& Becer. C.R. (2015). Lignocellulosic Biomass: A Sustainable Platform for Production of Bio-Based Chemicals and Polymers. Polymer Chemistry, 1-61.

Kamireddy, S. R., Li. J., Tucker. M., Degenstein. J, \& Ji. Y. (2013). Effects and Mechanism of Metal Chloride Salts on Pretreatment and Enzymatic Digestibility of Corn Stover. Industrial \& Engineering Chemistry Research, 52,1775-1782.

Kim, K. H., Dutta, T., Ralph, J., Mansfield, S. D., Simmons, B. A., \& Singh, S. (2017). Impact of Lignin Polymer Backbone Esters on Ionic Liquid Pretreatment of Poplar. Biotechnology Biofuels, 101(10), 110. 
Kim, K. H., Dutta, T., Sun, J., Simmons, B., \& Singh, S. (2018). Biomass Pretreatment Using Deep Eutectic Solvent from Lignin Derived Phenols. Green Chemistry, 20(4), 809-815.

Kristiani. A., Sembiring, K. C., Abimanyu, H., \& Aulia, F. (2013). Hidrolisis Lignoselulosa Pelepah dan Tandan Kosong Kelapa Sawit dengan Katalis Zirkonia Tersulfatasi. JKTI, 15 (2), 74-77.

Kuhad R.C., Gupta, R., Khasa, Y.P., \& Singh, A. (2010). Bioethanol Production from Lantana Camara (Red sage), Pretreatment, Saccharification and Fermentation. Bioresource Technology, 101, 8348-8354.

Kumar, P., Barrett, D. M., Delwiche, M. J. \& Stroeve, P. (2009a). Methods for Pretreatment of Lignocellulosic Biomass for Efficient Hydrolysis and Biofuel Production. Industrial and Engineering Chemistry Research, 48, 3713-3729.

Kumar. A., Sing, L.K., \& Ghosh, S. (2009b). Bioconversion of Lignocellulosic Fraction of Water-hyacinth (Eichhornia crassipes) Hemicelluloses Acid Hydrolysate to Ethanol by Pichia Stipitis. Bioresource Technology, 100, 3293-3297.

Li. B. Z, Balan, V., Yuan, Y. J. \& Dale, B. E. (2010). Process Optimization to Convert Forage and Sweet Sorghum Bagasse to Ethanol Based on Ammonia Fiber Expansion (AFEX) Pre-treatment. Bioresource Technology, 101, 1285-1292.

Li, S. \& Song, X. (2018). Study on The Preparation and Production Factors of A Direct Lignocellulose Biomass Fuel Cell. Journal of Electroanalytical Chemistry, 810, 55-61.

Limayem, A., \& Ricke, S. C. (2012). Lignocellulosic Biomass for
Bioetanol Production: Current Perspectives, Potential Issues and Future Prospects. Progress in Energy and Combustion Science, 38, 449-467.

Liong, Y. Halis, Y., R., \& Mohamed, R. (2013). Chemical Characterization of Imperata cylindrica ('Lalang') and Pennisetum purpureum (Napier grass) for Bioethanol Production in Malaysia. Pertanika Journal of Tropical Agricultural Science, 36, $109-116$.

Mais, U., Esteghlalian, A. R., Saddler, J. N. \& Mansfield, S. D. (2002). Enhancing The Enzymatic Hydrolysis of Cellulosic Materials Using Simultaneous Ball Milling. Applied Biochemistry and Biotechnology, 98(1), 815-832.

Mazaheri, H., Lee, K. T., Bhatia, S., \& Mohamed, A. R. (2010). Sub/supercritical Liquefaction of Oil Palm Fruit Press fiber for The Production of Bio-oil, Effect of Solvents. Bioresource Technology, 101(19), 7641-7647.

Menon, V. \& Rao, M. (2012). Trends in Bioconversion of Lignocellulose, Biofuels, Platform Chemicals \& Biorefinery Concept. Progress in Energy and Combustion Science, 8(4), 522-550.

Mohr, A. \& Raman, S. (2013). Lessons from First Generation Biofuels and Implications for The Sustainability Appraisal of Second Generation Biofuels. Energy Policy, 63, 114122.

Moodley, P. \& Kana, E. B. G. (2017). Development of A Steam or Microwave-assisted Sequential Salt-alkali Pretreatment for Lignocellulosic Waste, Effect on Delignification and Enzymatic Hydrolysis. Energy Conversion and Management, 148, 801-808.

Mosier, N., Hendrickson, R., Ho, N., Sedlak, M., \& Ladisch, M. R,. (2005). Optimization of $\mathrm{pH}$ 
Controlled Liquid Hot Water Pretreatment of Corn Stover. Bioresource Technology, 96(18), 1986-1993.

Nappu, B. M. (2013). Sebaran Potensi Limbah Tanaman Padi dan Jagung serta Pemanfaatannya di Sulawesi Selatan. Seminar Nasional Inovasi Teknologi Pertanian. Balai Pengkajian Teknologi Pertanian Sulawesi Selatan.

Nata, I. F., Prayogo, J. H., \& Arianto, T. (2014). Produksi Bioetanol dari Alkali-Pretreatment Jerami Padi dengan Proses Simultaneous Sacharification and Fermentation (SSF). Konversi, 3(1), 10-16.

Osvaldo, Z.S., Putra, S. P., \& Faizal, M. (2012). Pengaruh Konsentrasi Asam dan Waktu pada Proses Hidrolisis dan Fermentasi Pembuatan Bioetanol dari AlangAlang. Jurnal Teknik Kimia, 18(2), 52-62.

Pan, M., Zhao, G., Ding, C., Wu, B., Lian, Z., \& Lian, H. (2017). Physicochemical Transformation of Rice Straw after Pretreatment with A Deep Eutectic Solvent of Choline Chloride/Urea. Polymers, 176, 307-314.

Pan, X., Kadla, J.F., Ehara, K., Gilkes, N., \& Saddler, J.N. (2006). Organosolv Ethanol Lignin from Hybrid Poplar as A Radical Scavenger: Relationship Between Lignin Structure, Extraction Conditions, and Antioxidant Activity. Journal of Agriculture and Food Chemistry, 54(16), 5806-5813.

Pang, Z., Lyu, W., Dong, C., Li, H., \& Yang, G. (2016). High Selective Delignification Using Oxidative Ionic Liquid Pretreatment at Mild Conditions for Efficient Enzymatic Hydrolysis of Lignocellulose. Bioresource Technology, 214, 96101.

Phitsuwan, P., Sakka, K., \& Ratanakhanokchai, K. (2013).
Improvement of Lignocellulosic Biomass in Planta, A Review of Feedstocks, Biomass Recalcitrance, and Strategic Manipulation of Ideal Plants Designed for Ethanol Production and Processability. Biomass and Bioenergy, 58, 390-405.

Procentese, A., Johnson, E., Orr, V., Campanile, A. G., Wood, J. A., \& Rehmann, L. (2015). Deep Eutectic Solvent Pretreatment and Subsequent Saccharification of Corncob. Bioresource Technology, 192, 31-36.

Procentese, A., Raganati, F., Olivien, G., Russo, M. E., Rehmann, L., \& Marzocchella, A. (2017). Lowenergy Biomass Pretreatment with Deep Eutectic Solvents for Biobutanol Production. Bioresource Technology, 243, 464-473.

Reddy, N. \& Yang, Y. (2005). Biofibers from Agricultural Byproducts for Industrial Applications. Trend Biotechnology, 23(1), 22-27.

Sert, M., Aslanoglu, A., \& Ballice, L. (2017). Conversion of Sunflower Stalk Based Cellulose to The Valuable Products Using Choline Chloride Based Deep Eutectic Solvent. Renewable Energy, 118(C), 9931000.

Socha, A. M., Parthasarathi. R., Shi. J., Pattathil. S., Whyte. D., Bergeron. M., George. A., Tran. K., Stavila. K., Venkatachalam. S., Hahn. M. G., Simmons. B. A, \& Singh. S. (2014). Efficient Biomass Pretreatment Using lonic Liquids Derived from Lignin and Hemicellulose. PNAS. 111, E3587-E3595.

Sunardi \& Istikowati, W. T. (2012). Analisis Kandungan Kimia dan Sifat Serat Tanaman Purun Tikus (Eleocharis dulcis) Asal Kalimantan Selatan. Bioscientiae, 9(2), 15-25.

Tamunaidu, P. \& Saka, S. (2011). Chemical Characterization of Various Parts of Nipa Palm (Nypa 
fruticans). Industrial Crops and Products, 34, 1423-1428.

Wahlström, R. M. \& Suurnäkki, A. (2015). Enzymatic Hydrolysis of Hignocellulosic Polysaccharides in The Presence of Ionic Liquids. Green Chemistry, 17, 694-714.

Walker, G. M. (2010). Bioethanol, Science and Technology of Fuel Alcohol. Scotland: University of Abertay.

Wang, L., Yang., M., Fan, X., Zhu, X., Xu, T. \& Yuan, Q. (2011). An Environmentally Friendly and Efficient High-temperature-steaming Method for Xylitol Bioconversion with Corncob Hydrolysate by Adapted Candida tropicalis. Process Biocemistry, 46, 16191626.

Wu, W., Wang, Z., Jin, Y., Matsumoto, Y., \& Zhai, H. (2014). Effects of $\mathrm{LiCl} / \mathrm{DMSO}$ Dissolution and Enzymatic Hydrolysis on The Chemical Composition and Lignin Structure of Rice Straw. Biomass and Bioenergy, 71, 357-362.

Xu, G., Ding, J., Han, R., Dong, J., \& Ni, Y. (2016). Enhancing Cellulose Accessibility of Corn Stover by Deep Eutectic Solvent Pretreatment for Butanol Fermentation. Bioresource Technology, 203, 364369.

Yoon, L. W., Ngoh, G. C., Chua, M., Seak, A., \& Hashim, M. (2011). Comparison of Ionic Liquid, Acid and Alkali Pretreatments for Sugarcane Bagasse Enzymatic Saccharification. Journal of Chemical Technology and Biotechnology, 86(10), 1342-1348.

Yunus, R., Salleh, S. F., Abdullah, N., \& Biak, D. R. A. (2010). Effect of Ultrasonic Pretreatment on Low Temperature Acid Hydrolysis of Oil Palm Empty Fruit Bunch. Bioresource Technology, 101(24), 9792-9796.
Zhang, C., Xia, S., \& Ma, P. (2016). Facile Pretreatment of Lignocellulosic Biomass Using Deep Eutectic Solvents. Bioresource Technology, 219, 1-5.

Zhao, Y., Wang, Y., Zhu, J. Y., Ragauskas, A., \& Deng, Y. (2008). Enhanced Enzymatic Hydrolysis of Spruce by Alkaline Pretreatment at Low Temperature. Biotechnology Bioengineering, 99,1320-1328. 